\title{
UNIVERSITY EDUCATION AND TRAINING OF MICROBIOLOGISTS IN BRAZIL: 1990-2000
}

\author{
João Ruy Jardim Freire*; Enilson Luiz Saccol de Sá
}

Departamento de Solos, Faculdade de Agronomia, Universidade Federal do Rio Grande do Sul, Porto Alegre, RS, Brasil.

Submitted: November 22, 2003; Returned to authors: July 25, 2003; Approved: December 14, 2003.

\section{REVIEW}

\begin{abstract}
This paper aims to contribute to the discussion and concern on the future of microbiology in Brazil. This work presents a survey carried out in 2001 that shows a picture of Microbiology status in Brazil. Most of the conclusions are based on the data collected from the university courses and from the data supplied by the Brazilian National Research Council (CNPq) and the Coordination for the Improvement of Higher Level Personnel (CAPES). However, some of the affirmatives are more based on the experiences with postgraduate teaching in microbiology than on the data provided by official institutions. Such affirmatives were made in order to improve the development of the microbiology in Brazil. Also, a plan that proposes higher number of scholarships awarded to microbiology, to increase the possibility to form a critical mass necessary for further development of the Brazilian microbiology, is presented in order to produce discussion and more debate on the future of the Microbiology in Brazil.
\end{abstract}

Key words: education in microbiology, training of microbiologists, post-graduation in microbiology

\section{INTRODUCTION}

The Brazilian scientific community and research-funding agencies have for a long time been concerned about the present and future state of microbiology in the country, although the measures taken so far to support the development of science and technology in microbiology have been insufficient or cosmetic.

As long ago as 1982 the Brazilian Society for Microbiology (Sociedade Brasileira de Microbiologia, SBM) published an evaluation of postgraduate programs and in 1983 produced a wide-ranging plan, aimed at the Brazilian funding agencies, proposing the adoption of new measures for the financing of both research and technological development. In 1989, Leon and Barros (4) published a paper dealing with the difficulties on the post-graduation.

In 1990, the SBM, under the presidency of Professor Maria Therezinha Martins, produced a detailed Sectorial Program for Microbiology (6).
Some progress has occurred, but has been insufficient for further development. In 1988, Van Regenmortel et al. (5) carried out a survey in twenty countries for the Education Committee of the International Union of Microbiological Societies (IUMS). In the survey only two postgraduate microbiology courses were listed in Brazil; one at the Federal Rural University of Rio de Janeiro in veterinary microbiology and the other at the University of São Paulo (USP), in São Carlos, in biotechnology and treatment of water and effluents. However, it must be observed that the courses at USP in São Paulo and at the Federal University of Rio de Janeiro were not included in that survey.

In 1994, the first author organized with the Brazilian Society for Microbiology a meeting involving coordinators of postgraduate programs and microbiology professionals from companies and industries. This meeting was held at the SBM headquarters in the University of São Paulo and was supported by CNPq funds $(1,2)$. Also in 1994, the Brazilian National Research Council "Conselho Nacional de Desenvolvimento

*Corresponding author. Mailing address: Departamento de Solos, Faculdade de Agronomia, UFRGS. Av. Bento Gonçalves, 7712, C.P. 772. 91540-000, Porto Alegre, RS, Brasil. 
Científico e Tecnológico" (CNPq) implemented two important initiatives, one was the creation of the microbiology action program "Programa de Ação Induzida de Microbiologia" to make it easier for postgraduate students to take doctoral courses abroad while the other was the inclusion of biotechnology in the Human Resources in Strategic Areas program "Recursos Humanos em Áreas Estratégicas" (RHAE). However, the presentation of development projects to the RHAE program by companies depends on the participation of qualified professional microbiologists and there has been little real progress because of the scarcity of suitably qualified professionals (3).

Special round tables on the teaching and postgraduate training of microbiologists have been included in recent SMB congresses, but important recommendations produced have remained on paper and no effective action has been taken to implement them, probably because there was no sufficient pressure from the microbiology community besides isolated actions.

\section{UNDERGRADUATE STUDIES}

At present, undergraduate training of microbiologists takes place only at the Federal University of Rio de Janeiro (UFRJ) and the Federal University of Minas Gerais (UFMG) (Table 1). In 1997 an undergraduate baccalaureate microbiology course was started at the Federal University of Rio Grande do Sul (UFRGS), but the course has since been discontinued. However, the responses from a questionnaire sent to universities with postgraduate programs in microbiology in the year 2000 shows that the general opinion of those surveyed was that more undergraduate courses in microbiology are desirable and that indeed it would have placements available for microbiology graduates in companies, industry, clinical laboratories etc $(2,3)$.

Undergraduate training in microbiology as part of a baccalaureate in biological sciences depends on the availability to the student of adequate theoretical and practical courses, and does not necessarily lead to the production of qualified microbiologists - undergraduate courses specifically in microbiology being the most desirable means of producing graduates skilled in microbiology. The creation of specific microbiology courses would result in a critical mass of microbiologists and allow the expansion of microbiological research and development in Brazil. Those microbiology courses already exist in many industrialized countries as well as in the so called developing countries such as Columbia, Mexico, Peru and Chile. Because of the demands of industry and technological development it is inevitable that many more of such courses will have to be implemented in Brazil sooner or later.

According to the coordinator of the microbiology course at the Federal University of Rio de Janeiro (UFRJ) the undergraduate microbiology course was created in 1994 as a baccalaureate course with 35 full-time places. The average number of students
Table 1. Number of undergraduate degrees awarded in microbiology in Brazil during 1990-2000.

\begin{tabular}{cccc}
\hline \multirow{2}{*}{ Year } & \multicolumn{2}{c}{ University } & Total \\
\hline & UFMG $^{1}$ & UFRJ $^{2}$ & \\
1990 & 9 & - & 9 \\
1991 & 3 & - & 3 \\
1992 & 6 & - & 6 \\
1993 & 10 & - & 10 \\
1994 & 3 & - & 3 \\
1995 & 5 & - & 5 \\
1996 & 7 & - & 7 \\
1997 & 11 & 19 & 30 \\
1998 & 1 & 16 & 17 \\
1999 & 1 & 20 & 21 \\
2000 & 9 & 21 & 30 \\
\hline Total & 65 & 76 & 141 \\
\hline
\end{tabular}

${ }^{1}$ Federal University of Minas Gerais, data supplied by course coordinator Dr. Patricia Silva Cisalpino; ${ }^{2}$ Federal University of Rio de Janeiro, data supplied by course coordinator Angela Gonçalves da Silva.

applying for each place was about five in the first year of the course but rose to around eleven applications in 2001. Because of their high level of scientific training, undergraduates taking part in this course have been greatly sought-after by researchers and teachers at UFRJ and other institutions who have provided these students with "initiation into science" (iniciação científica) scholarships. Of the 45 students graduating up to the start of the year 2000, 36 entered postgraduate courses at UFRJ or other institutions in the region. The fact that a prospective postgraduate student has graduated in microbiology is very important for postgraduate courses in microbiology, because by choosing these graduates these courses can select candidates who have already been educated and trained in the basic disciplines of microbiology.

The coordination of the UFRJ microbiology course also stated that Brazilian industries (especially the biotechnology, environmental, food, pharmaceutical and related sectors) still has difficulties in recognizing the importance and worth of employing professional microbiologists. Such recognition is slow in coming and depends on employers being convinced of the benefits of employing qualified professionals who have graduated in microbiology and have practical training in this field as opposed to non-professional microbiologists such as pharmacists and biologists who have taken only one or two applied microbiology disciplines during their undergraduate studies.

The UFMG baccalaureate course produced 65 microbiologists between 1990 and the year 2000, the majority of graduates opting 
to enter into postgraduate courses, although some went to research institutes and foundations. Up to the year 2000, the courses at UFRJ and UFMG had between them produced 141 graduate microbiologists (Table 1).

The limited formation of professional microbiologists has been the main cause of the underdevelopment of microbiology in Brazil and the little development of technologies, industries and research at the universities. Areas such as enzymes, biopolymers, bacterial pigments, microbiology/biotechnology equipment, antibiotics etc., have had few initiatives. The delay in the establishment of technology applications had led to plans for microbiology industries being abandoned from the start of because of the impossibility of competition with foreign products.

The inexistence of a critical mass of professionals, in all levels, caused the stagnation of microbiology in the country. How to develop the research and technology applications with only postgraduates, professionals and, in many cases subutilized in routine work?

\section{POSTGRADUATE STUDIES}

In the past few years there has been some progress in the field of postgraduate education and training. From 1981 to 1986, an average of 31 master's level and 16 doctoral level students graduated each year from the four postgraduate microbiology courses which existed at that time. The average throughout time was 4.5 years for a master's program and 5 years for a doctoral program (1).

In October 2000 we sent a questionnaire to the 13 Brazilian universities that run postgraduate microbiology courses. We have received a response from ten (Table 2). The University of Campinas (UNICAMP), the Federal University of Lavras (UFLA) and the Federal University of São Paulo (UNIFESP), did not respond to the questionnaire. For the revision of this paper in August 2003, a request was sent again to those institutions and there was no response. The Universidade Estadual do Rio de Janeiro (UERJ) was included now in the survey. Table 2 shows that slightly more than 900 master's level microbiologists graduated during the ten years from 1990 to 2000, principally from UFMG, UFRJ and USP, with the annual number of students graduating at this level almost doubling over the decade from 57 in 1990 to 113 in the year 2000, the annual average from 1990 to 1996 being 73 while that from 1997 to 2000 was 109 (3).

Half of the universities with postgraduate programs in microbiology are in São Paulo state, i.e. USP (University of São Paulo in São Paulo and in Piracicaba at Escola Superior de Agricultura Luiz de Queiroz (ESALQ) campii), UNICAMP (State University of Campinas), UNESP (University of the State of São Paulo at Rio Claro and Jaboticabal campii) and the UNIFESP

Table 2. Master's degrees awarded at eleven Brazilian universities during 1990-2000, the results of a questionnaire sent in October 2000.

\begin{tabular}{|c|c|c|c|c|c|c|c|c|c|c|c|c|}
\hline \multirow[t]{2}{*}{ Year } & \multicolumn{11}{|c|}{ University $^{1}$} & \multirow[t]{2}{*}{ Total } \\
\hline & UFMG & UERJ & UFRJ & USP & UFV & UFRGS & $\begin{array}{c}\text { UEL } \\
\text { Rio Claro }\end{array}$ & $\begin{array}{l}\text { UNESP } \\
\text { ESALQ }\end{array}$ & USP & UNIFESP $^{2}$ & $\begin{array}{c}\text { UNESP } \\
\text { Jaboticabal }\end{array}$ & \\
\hline 1990 & 11 & - & 10 & 15 & 4 & 1 & - & - & 5 & 11 & - & 57 \\
\hline 1991 & 17 & - & 16 & 9 & - & 3 & - & 1 & 4 & 15 & - & 65 \\
\hline 1992 & 23 & - & 9 & 6 & 10 & 6 & 5 & 2 & 3 & 5 & - & 69 \\
\hline 1993 & 12 & - & 10 & 6 & 5 & 4 & 5 & 0 & 8 & 7 & - & 57 \\
\hline 1994 & 9 & - & 12 & 8 & 5 & 10 & 8 & 13 & 6 & 7 & - & 78 \\
\hline 1995 & 12 & - & 13 & 7 & 7 & 13 & 8 & 13 & 7 & 5 & - & 85 \\
\hline 1996 & 17 & - & 16 & 10 & 11 & 8 & 13 & 12 & 3 & 11 & - & 101 \\
\hline 1997 & 17 & 2 & 18 & 20 & 9 & 14 & 5 & 9 & 11 & - & - & 105 \\
\hline 1998 & 17 & 7 & 20 & 22 & 13 & 9 & 4 & 9 & 7 & - & - & 108 \\
\hline 1999 & 13 & 5 & 17 & 33 & 15 & 11 & 16 & 2 & 5 & - & 7 & 124 \\
\hline 2000 & 19 & 10 & 18 & 14 & 16 & 7 & 11 & 9 & 3 & - & 16 & 123 \\
\hline Total & 167 & 24 & 159 & 150 & 95 & 86 & 75 & 70 & 62 & 61 & 23 & 972 \\
\hline
\end{tabular}

${ }^{1}$ Key: UFMG = Federal University of Minas Gerais; UERJ = State University of Rio de Janeiro; UFRJ = Federal University of Rio de Janeiro; USP = University of São Paulo; UFV= Federal University of Viçosa; UFRGS = Federal University of Rio Grande do Sul; UEL = State University of Londrina; UNESP = University of the State of São Paulo; ESALQ = Escola Superior de Agricultura Luiz de Queiroz; UNIFESP $=$ Federal University of São Paulo; ${ }^{2}$ Data obtained from a questionnaire sent in 1996, this university did not respond to the questionnaire sent in the year 2000 and in 2003. 
(Federal University of São Paulo). This concentration of courses is apparently due to the degree of development of science and technology in the state of São Paulo. In UNICAMP microbiology is one of the areas of specialization within the Molecular Biology and Genetics Course, while Minas Gerais has three courses, one at UFMG, another at the Federal University of Viçosa (UFV) and a third at the Federal University of Lavras (UFLA).

There are few microbiology doctoral level programs in Brazil, the oldest being at UFRJ. Table 3 shows data for eight universities, and it can be seen that in the ten years between 1990 and the year 2000 about 300 doctoral students graduated, with about 29 doctorates being awarded per year between 1990 and 1996 and about 22 per year between 1997 and the year 2000. It should be noted that, because of the limited absorption capacity of Brazilian universities, in many areas doctoral studies were undertaken outside the country.

The low number of doctoral microbiologist in Brazil is reflected in the relatively small amount of original research carried on in the country which means that there is little development of applied technology and few locally developed technologies in microbiology and biotechnology. The low level of development in these areas is a consequence of the limited number of microbiology professionals graduating from the universities.

At the 20th and 21th Brazilian Microbiology Congresses, the first author of this paper presented data (supplied by the Biomedical Sciences Section of CNPq) that showed the number of postgraduate scholarships awarded (Table 4) to students of biochemistry, microbiology and plant and animal morphology from 1990 to 1996 (2,3). Data for the science areas for the period 1997 to 2000 are shown in Table 4, from which it can be seen that during this four-year period many more scholarships were awarded for biochemistry than for microbiology and that more scholarships were available to doctoral students than to master's level students, a clear inversion of priorities because master's students are the feed-stock for doctoral programs. By comparing the data from 1990 to 1996 (3), partially reproduced in Table 5, with that from 1997 to 2000 we can see that there was an increase in the number of microbiology scholarships awarded during these two periods. Data from the Biosciences (ex-Biomedical) Section of CNPq also show that the Microbiology Action Program of CNPq (Programa de Ação Induzida de Microbiologia), designed to provide scholarships for Brazilian students to study outside the country, provided six scholarships in 1996, five in 1997, seven in 1999 and four in the year 2000. This program was created by its organizers to benefit especially medical microbiology. The modest results of the program apparently reflecting this decision.

From 1990 to 2003 the award of scholarships in microbiology by the Coordination for the Improvement of the Higher Level Personnel (CAPES) of the Ministry of Education has varied from 60 in 1990 to 95 in 1994 of the master's level. In the doctorate, scholarships were 44 in 1991 and 71 in 1998. The data shows

Table 3. Doctoral degrees awarded at eight Brazilian universities during 1990-2000, the results of a questionnaire sent in October 2000.

\begin{tabular}{|c|c|c|c|c|c|c|c|c|c|}
\hline \multirow[t]{2}{*}{ Year } & \multicolumn{8}{|c|}{ University $^{1}$} & \multirow[t]{2}{*}{ Total } \\
\hline & UFRJ & UNIFESP $^{2}$ & $\begin{array}{c}\text { UNESP } \\
\text { Rio Claro }\end{array}$ & USP & UFMG & ESALQ & UFV & $\begin{array}{c}\text { UNESP } \\
\text { Jaboticabal }\end{array}$ & \\
\hline 1990 & 8 & 11 & - & 4 & - & - & - & - & 23 \\
\hline 1991 & 18 & 15 & - & 2 & - & - & - & - & 35 \\
\hline 1992 & 17 & 15 & 1 & 5 & - & - & - & - & 38 \\
\hline 1993 & 13 & 5 & 0 & 4 & - & - & - & - & 22 \\
\hline 1994 & 11 & 4 & 2 & 4 & - & - & - & - & 21 \\
\hline 1995 & 14 & 7 & 5 & 5 & - & - & - & - & 31 \\
\hline 1996 & 10 & 11 & 3 & 7 & - & - & - & - & 31 \\
\hline 1997 & 10 & - & 4 & - & 2 & - & - & - & 16 \\
\hline 1998 & 15 & - & 4 & - & 2 & - & - & - & 21 \\
\hline 1999 & 12 & - & 5 & - & 4 & 1 & - & - & 22 \\
\hline 2000 & 8 & - & 7 & - & 7 & 4 & 1 & 1 & 28 \\
\hline Total & 136 & 68 & 31 & 31 & 15 & 5 & 1 & 1 & 288 \\
\hline
\end{tabular}

${ }^{1}$ Key: UFRJ = Federal University of Rio de Janeiro; UNIFESP = Federal University of São Paulo; UNESP = University of the State of São Paulo; USP = University of São Paulo; UFMG = Federal University of Minas Gerais; ESALQ = Escola Superior de Agricultura Luiz de Queiroz; $\mathrm{UFV}=$ University of Viçosa; ${ }^{2}$ Data obtained from a questionnaire sent in 1996, this university did not respond to the questionnaire sent in the year 2000 and in 2003 . 
Table 4. Scholarships from the Brazilian National Research Council (CNPq) awarded in morphology, biochemistry and microbiology 1997-2000.

\begin{tabular}{|c|c|c|c|c|c|}
\hline \multirow[t]{2}{*}{ Type of Grant } & \multicolumn{4}{|c|}{ Year } & \multirow{2}{*}{$\begin{array}{l}\text { Total Number of } \\
\text { scholarships }^{1}\end{array}$} \\
\hline & 1997 & 1998 & 1999 & 2000 & \\
\hline \multicolumn{6}{|l|}{ POSTGRADUATE $^{2}$} \\
\hline \multicolumn{6}{|l|}{ Biochemistry } \\
\hline Master's & 135 & 109 & 97 & 122 & 463 \\
\hline Doctorate & 138 & 158 & 169 & 169 & 634 \\
\hline Total postgraduate scholarships in biochemistry & 273 & 267 & 266 & 291 & 1097 \\
\hline \multicolumn{6}{|l|}{ Microbiology } \\
\hline Master's & 45 & 39 & 38 & 42 & 164 \\
\hline Doctorate & 47 & 51 & 55 & 65 & 218 \\
\hline Total postgraduate scholarships in microbiology & 92 & 90 & 93 & 107 & 382 \\
\hline \multicolumn{6}{|l|}{ Plant and Animal Morphology } \\
\hline Master's & 54 & 43 & 38 & 19 & 154 \\
\hline Doctorate & 29 & 31 & 37 & 25 & 122 \\
\hline Total postgraduate scholarships in morphology & 83 & 74 & 75 & 44 & 276 \\
\hline
\end{tabular}

${ }^{1}$ These figures represent the average of the monthly payments paid from January to December (number of monthly payments for the year divided by 12 = the number of scholarships per year), and because of this the number of scholarships may be a fraction. However, the number of scholarships is not equivalent to the number of grantees because each 12 monthly payments made (equivalent to 1 grant-year) may have been given to 1 or more grantees; ${ }^{2}$ Data supplied by the Biosciences Section of the Brazilian National Research Council (CNPq).

Table 5. Number of postgraduate scholarships for microbiology awarded by the Brazilian National Research Council (CNPq) during the periods 1990-1996 and 1997-2000.

\begin{tabular}{lcc}
\hline Period and level & $\begin{array}{c}\text { Number of } \\
\text { scholarships }\end{array}$ & $\begin{array}{c}\text { Average Number of } \\
\text { scholarships per year }{ }^{1}\end{array}$ \\
\hline 1990-1996 $^{\mathbf{2}}$ & & \\
Master's & 160 & 23 \\
Doctoral & 86 & 12 \\
1997-2000 $^{3}$ & & \\
Master's & 164 & 41 \\
Doctoral & 219 & 5 \\
\hline
\end{tabular}

${ }^{1}$ Rounded to nearest whole number; ${ }^{2}$ Provided by the Biomedical Sciences Section of CNPq (2); ${ }^{3}$ Provided by the Biosciences (exBiomedical Sciences) Section of CNPq.

that in the average there was no significant increase in the interest on microbiology scholarships (Table 6). In average, the total of MSc scholarships awarded per year by CAPES (19902000) plus those awarded by CNPq (1990-2000) was 119.3 while those of the doctoral level was 90.8 .
The postgraduate courses in Agriculture Microbiology (UFRGS, USP-ESALQ and UFV) cover also in general research areas other than those of agricultures such as biodegradation, biodeterioration, microbiology of water and effluents etc. Those universities formed 243 masters and six doctorates from 1990 to 2000 (Tables 2,3).

\section{MICROBIOLOGY IN OTHER POSTGRADUATE COURSES}

Some universities with postgraduate courses e.g. Pharmacy at USP offer training and opportunity of research in applied microbiology. These professionals so formed are capable for activity in areas such as food microbiology, cosmetics, laboratories of clinical analysis, etc. In a way they have cover the deficiency of professionals wit none complete education and training in basic and applied microbiology.

\section{Educational background of postgraduate microbiologists}

Taking as an example the master's course in Agricultural and Environmental Microbiology (Microbiologia Agrícola e do Ambiente) at UFRGS, 75\% of postgraduate-level entrants come from undergraduate biology courses, $20 \%$ from pharmacy and the rest from diverse courses such as Agronomy, Chemistry 
Table 6. Scholarships * awarded by the Coordination for the Improvement of the Higher Level Personnel (CAPES) in microbiology for 1990-2000.

\begin{tabular}{lccc}
\hline \multicolumn{4}{c}{ Post -graduate level } \\
\hline Year & Master & Doctoral & Total \\
\hline 1990 & 60 & 56 & 117 \\
1991 & 71 & 44 & 115 \\
1992 & 79 & 47 & 126 \\
1993 & 85 & 45 & 130 \\
1994 & 95 & 49 & 144 \\
1995 & 81 & 55 & 136 \\
1996 & 91 & 61 & 152 \\
1997 & 65 & 48 & 113 \\
1998 & 93 & 71 & 164 \\
1999 & 73 & 66 & 139 \\
2000 & 76 & 61 & 137 \\
\hline Total & 869 & 603 & 1472 \\
\hline
\end{tabular}

* Data provided by the Secretariat of the Presidency of CAPES

and Veterinary Sciences. The predominance of candidates with a background in biological sciences appears to be common to Brazilian postgraduate microbiology courses.

In Brazil, the Conselho Federal de Educação (now "Conselho Nacional de Educação") of the Ministry of Education (Ministério de Educação, MEC) had established a minimum curriculum for the undergraduate biological sciences courses. This curriculum included disciplines such as geology and paleontology but not microbiology, the consequence of this absurdity being that microbiology was generally not offered either as an optional or mandatory subject during the courses, with not even an emphasis being placed on microbiology as in subjects such as botany, zoology etc. Only recently have some biology courses begun to correct this anomaly, which appears to have developed because the CFE followed the old concept that microbiology was a medical science.

Most entrants to Brazilian postgraduate microbiology courses have little or no theoretical knowledge or practical training in microbiology, which means that most postgraduate microbiology courses have to correct these deficiencies by means of unit courses in basic microbiology, e.g. the master's course at UFRGS has obligatory unit courses in basic microbiology, microbial genetics and microbial physiology. An exception to this rule is the master's course in microbiology offered by the UFRJ, because most of the entrants to this course come from the undergraduate baccalaureate degree course in microbiology offered by this university.

\section{The role of private universities in educating microbiologists}

Why is it that the private universities in Brazil do not offer either undergraduate or postgraduate microbiology courses? One answer to this question may be that because so few undergraduate or postgraduate microbiologists graduate in Brazil there are a few biotechnology institutions, little research and development in microbiology and, consequently, little commercial interest in microbiology as a subject. The only large microbiologically based commercial activity is alcohol production, with little or no production of antibiotics, biopolymers, enzymes, microbial pigments, vaccines etc. How much is spent on the importation of these products and the payment of royalties by the few Brazilian companies active in these areas is not well known, but the importation of expensive

Table 7. Fate of postgraduates as reported by the courses in which they were matriculated (\%).

\begin{tabular}{|c|c|c|c|c|c|c|}
\hline \multirow[t]{3}{*}{ Fate of postgraduates } & \multicolumn{6}{|c|}{ University $^{1}$ and degree obtained } \\
\hline & \multicolumn{2}{|c|}{ UFRJ } & \multirow{2}{*}{$\frac{\text { USP }}{\text { Master's }}$} & \multirow{2}{*}{$\frac{\text { UFV }}{\text { Master's }}$} & \multirow{2}{*}{$\frac{\text { UFRGS }}{\text { Master's }}$} & \multirow{2}{*}{$\begin{array}{c}\text { ESALQ } \\
\text { Master's }\end{array}$} \\
\hline & Master's & Doctoral & & & & \\
\hline University Teaching/research & 26 & 78 & 54 & 38 & 50 & 70 \\
\hline Research institutes & & 10 & 26 & 12 & 30 & \\
\hline Doctorate & 33 & & & 17 & 4 & \\
\hline Industry & & & 16 & 5 & 16 & \\
\hline Diagnostic Laboratory & 18 & & 4 & & & \\
\hline Secondary school teaching & 5 & & & 10 & & \\
\hline Self-employed & & & & & & 30 \\
\hline Unknown & 18 & 12 & 0 & 18 & 0 & 0 \\
\hline
\end{tabular}

${ }^{1}$ Key: UFRJ = Federal University of Rio de Janeiro; USP = University of São Paulo; UFV= Federal University of Viçosa; UFRGS = Federal University of Rio Grande do Sul; ESALQ = Escola Superior de Agricultura Luiz de Queiroz. 
microbial products is high. One example, which may be cited, is the high-value polysaccharide polymer xanthan gum, 130 tons of which are imported each year for use mainly in the food and cosmetics industries at an annual cost of about 10 million US dollars (based on the 1996 Sigma price of 87 US\$ per Kg). Even in the medical sphere there is high necessity for qualified microbiologists, reflected in the fact that, in 2001, only $30 \%$ of Brazilian hospitals maintain a Hospital Infection Control Committee (Comissão de Controle de Infecção Hospitalar) and a microbiological monitoring program to control the level of hospital acquired infections, as established by regulation 2616/ 1998 of Health Minister, data from Hospital Infection Control Program of National Sanitary Vigilance Agency of Health Minister (ANVISA). It appears that the private universities are responding to a vicious circle in which lack of microbiological research and development caused by having few microbiologists causes a scarcity of microbiologists because there is no microbiological research and development in which they can be employed. In other words, outside the pharmaceutical companies, which commonly import technology and active ingredients, there is no critical mass of employers.

\section{Postgraduate employment}

The majority of postgraduates have been absorbed into teaching and research, industry, environmental agencies and clinical laboratories. We were informed by UFRJ that $33 \%$ of students with master degree continued as doctoral students while $18 \%$ went on to work in clinical laboratories. Data supplied by USP show that $56 \%$ of their postgraduates entered into teaching and research, $25 \%$ into teaching and $17 \%$ into industry (Table 7). The message coming from all the courses was that there was no problem in placing recently graduated students.

\section{PROBLEMS FACED BY POSTGRADUATE MICROBIOLOGY COURSES}

\section{Availability of scholarships}

All of the courses which responded to the questionnaire sent in the year 2000, except that at UFRGS, pointed out that the availability of sufficient scholarships was the main problem faced by the courses in attending the demand for places and increasing the number of postgraduate microbiologists.

Most postgraduate scholarships are awarded by the federal agencies CNPq and CAPES (Tables 4,5,6), although some smallscale funding comes from state research-supporting agencies (Fundação de Amparo à Pesquisa do Estado, FAPE) such as those in São Paulo (FAPESP), Minas Gerais (FAPEMIG) and Rio de Janeiro (FAPERJ). For example, according to the coordinator of the postgraduate microbiology course at UFRJ, in 1999 there were 72 candidates for the masters course but it was possible to accept only 11 of these due to the number of scholarships available. In general, the ratio of candidates applying to those selected and matriculated depends on the number of scholarships available and not on the quality of the candidates.

According to the biosciences coordination department of $\mathrm{CNPq}$, the cost of financing a master's student for 24 months was about R $\$ 17.000,00$ (6,000 US dollars at a conversion rate of $2.8 \mathrm{Real}(\mathrm{R} \$)$ to the dollar), while that of a doctoral student was about R \$ 51.000,00 (18,000 US dollars) over 48 months. Between 1997 and 2000, CNPq spent R \$2,8 million (about 3 million dollars) on 164 master's students and about R\$ 11 million (4 million dollars) on 219 doctoral scholarships.

\section{Availability of teaching resources}

Another point raised by all the universities responding to our questionnaire was the limited availability of funds for teaching resources. Apart from bench fees (paid by CAPES and $\mathrm{CNPq}$ ) the postgraduate courses have to fight against a lack of resources to maintain and increase the quality of the professional microbiologists they produce. The resources used in this fight generally come from research projects, this being especially true of courses in the state of São Paulo, where there has been extraordinary modernization of laboratories and general infrastructure thanks to help from the state researchfunding organ FAPESP.

Due to the difficulty in their maintenance and development, postgraduate microbiology courses alone are not, and will not be, able to give a significant contribution to the development of microbiology in Brazil. Undergraduate courses in microbiology, if more widely available in the country, will provide the critical mass of microbiologists necessary for such development.

\section{Lack of teaching-staff}

The lack of university teachers, the need to set up new unit courses, and the new contracts for teaching staff were described by three of the universities consulted as limiting their capacity to teach microbiology at postgraduate level. These three universities, in common with the others surveyed, are publicly funded either by federal or state governments. Because of this, in general, it is not easy to contract enough temporary or permanent teaching staff to satisfy the high demand for places by candidates or to implement research programs in important development areas. This lack of teaching staff and researchers reflects not only on the production of professional microbiologists but also on the level of research and development in the country.

It can be seen from Tables 2 and 3 that over a decade about 1260 postgraduate professional microbiologists have graduated in Brazil, that is about 126 per year (UNICAMP, UFLA and UNIFESP did not respond to our questionnaire, so the actual numbers are probably a little higher). As a result of this relatively small annual number of trained microbiologists, commercial industries, laboratories and teaching institutions have been forced to employ professionals from other disciplines who have little or no formal education or practical training in microbiology. 


\section{A DEVELOPMENT PLAN FOR MICROBIOLOGY IN BRAZIL}

Our survey of postgraduate microbiology courses in Brazil revealed two main factors preventing the production of qualified professional microbiologists: (a) the limitation in the number of scholarships available and (b) the scarcity of resources for the infrastructure and maintenance of the courses. As well as these direct and immediate factors, the courses surveyed also considered that the teaching of microbiology as a specific undergraduate degree course is both desirable and important for the development of microbiology in the country.

A superficial evaluation of the Microbiology Action Program and the RHAE biotechnology program points to the need for a revision of these programs in order to make them more dynamic.

Brazilian production of microbial derivatives such as antibiotics, biopolymers, enzymes and pigments and products such as diagnostic kits and laboratory equipment as well as the development of appropriate local technologies depends on a critical mass of qualified professionals dedicated to scientific research and the development of technological applications for this research. Such a critical mass will not be reached by the current slow growth of the human resources so vital for overturning the current trend. Only the large-scale application of resources to the creation of properly trained personnel will have any impact on the current underdeveloped state in which Brazilian microbiology-related science and technology finds itself.

\section{Availability of scholarships}

We consider valid the notion that the limited availability of professional microbiologists in Brazil has inhibited research and technological development and that the principal limiting factor to the availability of suitably qualified professionals is the low number of scholarships available.

As a first step towards development we estimate that in the next ten years Brazil needs to produce about 5,000 master's level and 2,500 doctoral level microbiologists. For this to occur, CNPq and CAPES should make available 750 scholarships per year divided between 10 universities, each of which would produce 50 master's level graduates and 25 doctoral graduates per year. If the cost of financing a master's student for 24 months is about R \$ 17.000,00 (6,000 US dollars at a conversion rate of $2.8 \mathrm{Real}(\mathrm{R} \$)$ to the dollar), while that of a doctoral student is about R \$ 51.000,00 (18,000 US dollars) over 48 months, the overall cost of 50 masters level scholarships per year would be $\mathrm{R} \$ 425.000,00$ (just over 151,000 US dollars), and 25 doctoral graduates per year at a cost of $\mathrm{R} \$ 318.750,00$ (just over 113,000 US dollars). This gives a total yearly cost for the 10 universities of $\mathrm{R} \$ 4,25$ million (about 1.52 million dollars) for microbiologists qualified to master level and about $\mathrm{R} \$ 3,19$ million (about 1.14 million dollars) for doctoral level microbiologists. The total cost over 10 years would be about $\mathrm{R} \$ 74,4$ million (around 26.6 million US dollars, less than the ten-year cost of importing xanthan gum (100 million US dollars), only one of the many imported microbial products. The above plan would have an annual cost of about R \$ 7,44 million (2.66 million US dollars), only a small part of the total CNPq and CAPES budgets and a small price to pay in the light of the benefits that such a program would bring to Brazilian scientific and technological development. An important question that should be posed is how much does the present technological backwardness in microbiological sciences cost the country.

If implemented, this plan should have its own management program for extra scholarships and should be accompanied by a marketing program by the funding agents and the Brazilian Society for Microbiology.

\section{Infrastructure and equipment}

The second principle problem faced by postgraduate programs is the limited resources available in terms of infrastructure and equipment. The resources that are available come mainly from research projects and with the exception of those projects funded by FAPESP (Fundação de Amparo à Pesquisa de São Paulo) these resources are generally limited. To tackle these deficiencies we propose the setting-up of a microbiology fund by $\mathrm{CNPq}$ or the federal research-funding organ FINEP (Financiadora de Estudos e Projetos).

\section{Incentives for creating undergraduate microbiology courses}

Any development plan for Brazilian microbiology should also address the need for undergraduate courses in this subject. Mechanisms and incentives needed to be established so that public and private universities will install courses in microbiology.

It is evident that a greater number of undergraduates trained in microbiology entering the universities and industry will have a direct effect on the development of Brazilian science and technology, and, indirectly, on the universities by the installation of undergraduate courses in response to the need for qualified personnel.

\section{Reevaluation of funding programs}

The Microbiological Action Program (Programa de Ação Induzida de Microbiologia) and the human resources program, RHAE, for biotechnology need to be reevaluated. These programs are passive in that the administrators of these programs wait for projects and/or candidates to be presented to them. There is no visible marketing plan to publicize the availability of resources linked to these programs, nor is there any plan of incentives for universities or companies to present projects or for industries to implement technical development 
projects. The limited results obtained by the microbiology action program and RHAE programs indicate the necessity to reform them (especially the former) and make them more dynamic by the inclusion of other areas of microbiology apart from medical microbiology. Industrial and environmental microbiology are two areas that are important for the technological development of Brazilian microbiology.

\section{PERSPECTIVES IN MICROBIOLOGY - A CHALLENGING FUTURE}

The origins of microbiology lie in the study of human and animal health, which has resulted in the general idea that all microorganisms are pathogenic - little being known of their beneficial effects.

Soil microbiology, in particular the study of nitrifying bacteria from the genera Nitrosomonas and Nitrobacter and nitrogenfixing bacteria from the large family Rhizobiaceae, has changed the popular conception of bacteria as being mere agents of disease. There is a new awareness that microorganisms recycle organic nutrients and convert inorganic minerals, including carbon dioxide, and are fundamental in the ecology and health of the planet.

Human population growth and the demand for food and material goods has led to the formation of the discipline of environmental microbiology which includes monitoring the microbiota of water, biodegradation (the treatment of agricultural, household and industrial residues and effluents), bioremediation of polluted areas and the study of the biodeterioration of materials and cultural artifacts. The study of all these areas has shown extraordinary growth in Brazil over the past few years, especially in São Paulo.

Pelczar (5), pointed out that the decade 1990-1999 would be known as the decade of education, the environment and the economy, and that microbiology would contribute significantly to these areas. Microbiology has contributed to our understanding of the biochemistry of living systems and the development of molecular genetics has resulted largely from the study of microorganisms. In regard to the environment, there is increasing emphasis laid on microbial recycling, bioremediation and the use of microbial-based bioinsecticides to replace chemical products. It seems that the forecasts of Pelczar have been realized, and we should note that this respected researcher and author also emphasized the need for education and training in microbiology.

Progress in microbiology will bring more development in the following areas, as adapted from the "Programa Setorial de Microbiologia" (4):

Basic microbiology - biochemistry, physiology, taxonomy, morphology and genetics of microorganisms;

Human and veterinary microbiology - monitoring and control of hospital infections, preventive medicine of epidemics, sanitary microbiology, clinical microbiology, studies and control of animal diseases and vectors;

Environmental microbiology - monitoring of the microbial pollutions of air and water, studies of biodegradation of wood, construction materials and biocorrosion of metals, bioremediation of organic, industrial and urban soil pollutants;

Agriculture microbiology - biological nitrogen fixation, biological control of insects and plant diseases by microorganisms, microbial soil ecology and interactions with soil pollution;

Food Microbiology - studies and quality control of food, agents of alimentary toxicity and infections;

Industrial microbiology - development and optimization of fermentative processes for the production of biopolymers, enzymes, aminoácidos, antibiotics, pigments, food and fuels, development of laboratory equipments.

\section{ACKNOWLEDGEMENTS}

The authors have many thanks to Professor Valderez Gambale (USP) for the important documents, help and the joint production of the paper published in the World Journal of Microbiology and Biotechnology, and to Dr. Robert W.S.P. Thomas for the translation and suggestions for the improvement of the manuscript.

\section{RESUMO}

\section{Educação universitária e treinamento de microbiologistas no Brasil: 1990-2000}

Este artigo visa contribuir para a discussão relacionada ao futuro da microbiologia no Brasil. Este trabalho apresenta um levantamento, realizado em 2001, que mostra um quadro da situação atual da microbiologia no Brasil. A maioria das conclusões são fundamentadas nos dados coletados dos cursos universitários e dos dados fornecidos pelo Conselho Nacional de Pesquisa (CNPq) brasileiro e pela Coordenação para o Aperfeiçoamento de Pessoal de Nível Superior (CAPES). No entanto, algumas das afirmativas são baseadas mais nas experiências de ensino de pós-graduação em microbiologia do que nos dados fornecidos pelas instituições oficiais. Tais afirmativas foram feitas no sentidos de incrementar o desenvolvimento da microbiologia no Brasil. Além disso, é apresentado um plano que propõe maior número de bolsas concedidas para a área de microbiologia, para aumentar a possibilidade de formar uma massa crítica necessária para maior desenvolvimento da microbiologia brasileira, visando produzir discussão e mais debate sobre o futuro da microbiologia no Brasil.

Palavras-chave: ensino de microbiologia, treinamento de microbiologistas, pós-graduação em microbiologia 


\section{REFERENCES}

1. Freire, J.R.J.; Gambale, V. Teaching of microbiology in Brazil: progress or stagnation. World J. Microbiol. Biotechnol., 12:307310, 1996.

2. Freire, J.R.J. A formação de recursos humanos em microbiologia. Centro de Recursos Microbiológicos, Boletim. XX Congresso Brasileiro de Microbiologia, Salvador, Bahia, 1999.

3. Freire, J.R.J.; Sá, E.L.S. A formação de microbiologiastas no Brasil. Centro de Recursos Microbiológicos. Boletim. XXI Congresso Brasileiro de Microbiologia, Foz do Iguaçu, PR, 2001.
4. Leon, W.; Barros, D.I.M. O ensino da microbiologia no Brasil: Um desafio. Revista de Microbiologia, 20:382-386, 1989.

5. Pelczar, M.J. Microbiology education in the United States: the issue of balance. World J. Microbiol. Biotechnol., 7:517-521, 1991.

6. Sociedade Brasileira de Microbiologia. Programa Setorial de Microbiologia. Coordenação Profa. Maria Therezinha Martins (Não publicado), 1990

7. Van Regenmortel, M.H.V.; Colwell, R.R.; Haghlghi, L.; Loutit, M.W.; Okafor, N. Opportunities for training in microbiology adapted to the needs of third world Countries. World J. Microbiol. Biotechnol., 6:437-446, 1990. 